\title{
THE TRABUCO AND BAKER CONGLOMERATES OF THE SANTA ANA MOUNTAINS
}

\author{
W. P. POPENOE
}

Reprinted for private circulation from The Journal of Geology, Vol. XLIX, No. 7, October-November r94I PRINTED IN THE U.S.A.

Balch Graduate School of the Geological Sciences California lnstintie of Technology Pasadena, California Contribution No. 325 


\title{
THE TRABUCO AND BAKER CONGLOMERATES OF THE SANTA ANA MOUNTAINS
}

\author{
W. P. POPENOE \\ California Institute of Technology
}

\begin{abstract}
A thick conglomerate series unconformably overlies Triassic metamorphics and Jura-Cretaceous intrusives and probably conformably underlies marine early Upper Cretaceous sandstones. The lower $300-400$ feet of this series are deeply weathered, red, soft, massive; the upper roo feet are fresh, greenish-gray to brown, resistant, thick bedded, and probably marine. The red lower part, named the "Trabuco formation" by E. L. Packard, was interpreted as a continental deposit older than the overlying gray conglomerate, and by Bernard Moore as a marine deposit continuous with and genetically inseparable from the gray conglomerate but weathered to its present condition by circulating iron-bearing meteoric waters after the deposition of the entire conglomerate series.

Field studies of the conglomerates and pebble counts show that the upper and lower conglomerates are probably conformable and have no constant differences in composition, size, or rounding of the included pebbles. The marked and constant differences in color, consolidation, and topographic expression are believed due to differences in weathering. The Trabuco conglomerate is interpreted as a flood-plain deposit weathered deeply in place before deposition of the gray marine conglomerate overlying. The Trabuco conglomerate is thus recognized as a valid formation, confirming Packard's original interpretation.
\end{abstract}

\section{THE PROBLEM}

At the base of the known marine Upper Cretaceous of the Santa Ana Mountains, Orange County, California, is a thick conglomerate series lying with pronounced angular unconformity upon a basement of metamorphosed Triassic sediments and associated, questionably Jurassic, intrusives. The conglomerates grade up into sandstones and shales that bear a typical marine early Upper Cretaceous fauna. The conglomerates are almost wholly unfossiliferous. Their thickness is variable but averages $400-500$ feet. The lower part of the conglomerates is a red, incoherent, rather structureless member that averages 300-400 feet thick; the upper member, which maintains an average thickness of near roo feet, is light-gray to brownish-gray, firmly cemented, thick bedded, and sufficiently resistant to maintain a bold cliff face above the weak red beds below. The red lower part of the conglomerates was named "Trabuco formation" by E. L. Packard in I9I6 and was thought to be nonmarine, whereas the upper gray conglomerate was believed to be marine. B. N. Moore, in 
I930, disputed the nonmarine origin of the Trabuco formation, believing it to be a weathered basal phase of the entire conglomerate series. He concluded that it had no status as a distinct formation.

This paper presents the results of a restudy of the conglomerates and attempts to determine which of the views outlined above is best supported by the geological evidence.

\section{HISTORICAL REVIEW}

First mention of the Trabuco conglomerates appears in a contribution by Packard ${ }^{\mathrm{x}}$ in I9I4 to a discussion by R. E. Dickerson on the general geology of the Santa Ana Mountains. Packard mentioned the characteristic color of the rock, stated that basic igneous rocks were the principal constituents, and contrasted the conglomerate with the gray conglomerate overlying. He suggested that the red beds might be a stream deposit. In I9I6 Packard $^{2}$ discussed the composition and relationships of the conglomerates in more detail. The two members were thought to be possibly unconformable, but direct evidence for this was lacking. Most of the igneous rocks in the Trabuco were said to be basic, while the upper gray conglomerate had a higher content of quartzites and cherts. W. A. English ${ }^{3}$ in I 926 mentioned the presence of the Trabuco formation in the northern Santa Ana Mountains but limited his discussion almost entirely to quotations from the I9I6 article by Packard. A. O. Woodford ${ }^{4}$ in 1926 noted the presence of a soft red conglomerate at the base of a thick series of "Chico" conglomerates in the neighborhood of Lucas Canyon in the southeastern part of the Corona quadrangle, southern Santa Ana Mountains. These conglomerates were said to be "suggestive of the Trabuco formation to the north." T. S. Southwick ${ }^{5}$

I "The Martinez and Tejon Eocene and Associated Formations of the Santa Ana Mountains," Univ. Calif. Pub., Bull. Deft. Geol. Sci., Vol. VIII, No. I I (I9r4), pp. $262-63$.

2 "Faunal Studies in the Cretaceous of the Santa Ana Mountains of Southern California," ibid., Vol. IX, No. I2 (rgr6), pp. I40-41.

3 "Geology and Oil Resources of the Puente Hills Region, Southern California," U.S. Geol. Surv. Bull. 768 (1926), pp. 17-18.

" "The San Onofre Breccia: Its Nature and Origin," Univ. Calif. Pub., Bull. Dept. Geol. Sci., Vol. XV, No. 7 (1925), p. I73.

5 "Geology of a Portion of the Santa Ana Mountains"' (Master's thesis, Calif. Inst. Technology, I928). 
mapped an area in northern San Diego and southern Orange counties approximately between San Juan Hot Springs and San Onofre. At the base of the Cretaceous section he noted a soft red unfossiliferous conglomerate $\mathrm{I} 50$ feet thick underlying harder and lighter-colored conglomerates of Upper Cretaceous age. The red conglomerate extended south of the area included in the map, and its distribution south of this point is not well known. Southwick repeated the suggestion that the Trabuco conglomerate may be nonmarine. B. N. Moore $^{6}$ in 1930 discussed the Trabuco conglomerate at some length in a general geologic study of the portion of the Santa Ana Mountains lying between Silverado and San Juan canyons. He concluded that the Trabuco conglomerate is an altered phase of the basal Cretaceous marine conglomerate; that the agencies of alteration are unknown but that circulation of meteoric iron-bearing waters was involved; that the more advanced alteration of the Trabuco resulted from its greater permeability and its greater content of ferruginous minerals. Finally, Moore stated that in his opinion the Trabuco has no valid basis as a distinct formation and that it should be considered as one with the superjacent unaltered conglomerates. Leo G. Hertlein and U. S. Grant ${ }^{7}$ in 1939 referred to the Trabuco formation 269 feet of decomposed red conglomerate not exposed at the surface but penetrated in deep wells in the vicinity of San Diego and lying below Chico conglomerates and sandstones and above the Black Mountainformation of metamorphosed sedimentaries and intrusives.

THE EVIDENCE

In connection with a study of the Upper Cretaceous stratigraphy and fauna of the Santa Ana Mountains, I mapped in detail the Trabuco conglomerate and the overlying gray conglomerate in the area between Trabuco and Black Star canyons. The gray conglomerate will hereafter be called the "Baker conglomerate" in accordance with the names first used in a report on the fauna of the area. ${ }^{8}$ The

6 "Geology of the Southern Santa Ana Mountains, California" (Doctor's thesis, Calif. Inst. Technology, 1930), pp. v, 52-54.

7 "Geology and Oil Possibilities of San Diego County, California," State Mining Bureaut, 35th Ann. Rept. State Mineralogist (January, I939), pp. 74-76.

${ }^{8}$ W. P. Popenoe, "Upper Cretaceous Mollusca from Southern California," Jour. Paleontol., Vol. XI, No. 5 (1937), p. 380. 
approximate surface outcrop of these conglomerates is shown on the map of the area (Fig. I), while the characteristics of the members with their relationships to the remainder of the Cretaceous section and to the basement are summarized in the diagram (Fig. 2). The

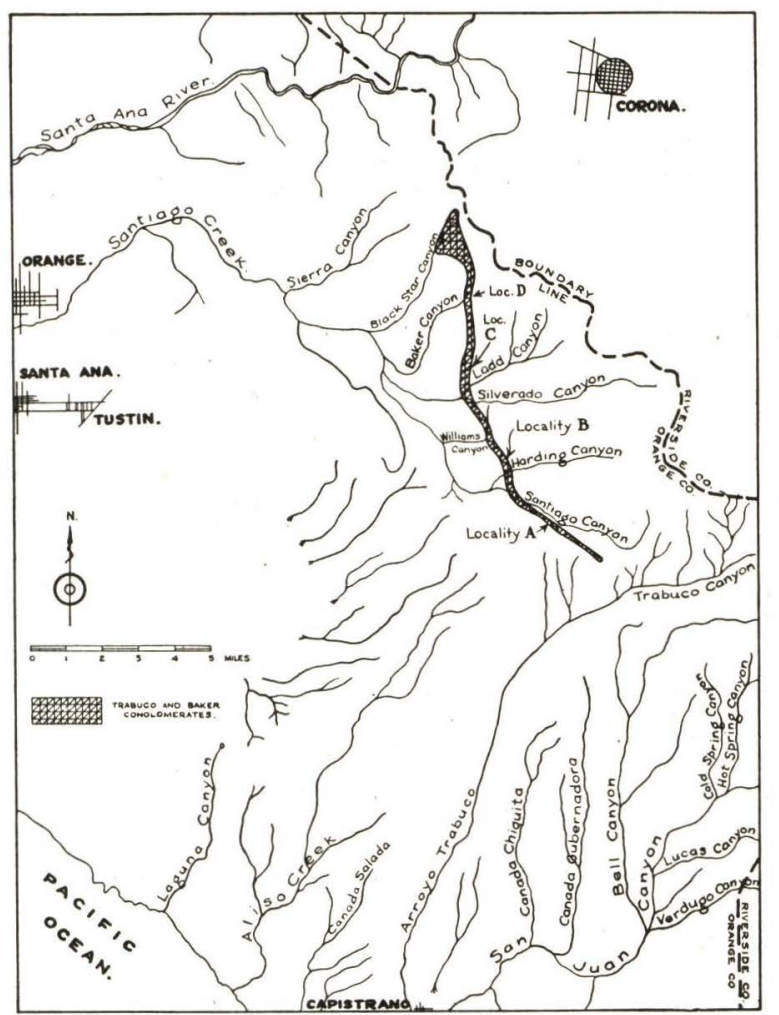

FIG. I.-Sketch map of parts of Orange and Riverside counties, California, showing exposure area of Trabuco and Baker conglomerates.

top of the Trabuco was mapped at the level where the conglomerates change from red to gray and from loose and friable to well-consolidated and hard.

Pebble counts of approximately a hundred pebbles were made at four different stratigraphic levels at each of four localities spaced at approximately 2-mile intervals along the strike. The positions of these localities are indicated on the sketch map. The four strati- 
graphic levels sampled at each locality are: station I, about Io-25 feet above the base of the Trabuco conglomerate; station 2, ap-

\begin{tabular}{|c|c|c|c|}
\hline$\frac{\pi}{\frac{\alpha}{\alpha}}$ & \multicolumn{3}{|c|}{$\begin{array}{l}\text { Conglomerates, sandstones and clays with occasional thin } \\
\text { coal beds. Mostly of Martinex Eocene age Partly marine, } \\
\text { partly non-marine. }\end{array}$} \\
\hline \multirow{4}{*}{$\begin{array}{l}0 \\
\text { on } \\
0 \\
0 \\
\omega \\
0 \\
\alpha \\
\vdash \\
\omega \\
\alpha \\
0\end{array}$} & \multirow{2}{*}{ 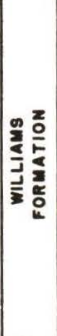 } & 蛋 & $\begin{array}{l}\text { Thin-bedded, light-colored, ferruginous, micaceous, } \\
\text { and shaly sandstones alternating with more massive beds } \\
\text { of calcareous sandstones or sandy limestones. Locally highly } \\
\text { fossiliferous. Marine. Thickness about } 520 \mathrm{ft} \text {. }\end{array}$ \\
\hline & & №n & $\begin{array}{l}\text { Soft, lighr-qrey to white, highly feldspathic and } \\
\text { micaceous conqlomerates and conglomeratic sandstones. } \\
\text { Unfossillferous. Marine? Average thickness } 200 \mathrm{ft} \text {. } \\
\text { HNGONFORMHY }\end{array}$ \\
\hline & \multirow{2}{*}{ 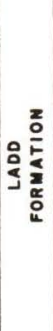 } & 올 & $\begin{array}{l}\text { Soft, brownish-qrey to bluish-grey micaceous sandy } \\
\text { shale or siltstone, with locally developed arkosic sandstones } \\
\text { and thick conglomerate lenses. Marine. Highly fossiliferous } \\
\text { in the upper half. Thickness } 1500 \mathrm{ft} \text {. or less. }\end{array}$ \\
\hline & & 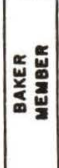 & $\begin{array}{l}\text { Light-colored, rather firmly cemented, cliff-forming } \\
\text { boulder conglomerate bolow grading upward into coarse } \\
\text { arkosic sandstones above. Sandstones become progress- } \\
\text { ively finer toward the top of the section and grade into } \\
\text { the Holz shale. Highly fossiliferous in the upper half. } \\
\text { Marine. Thickness approximately } 100 \mathrm{ft} \text {. }\end{array}$ \\
\hline 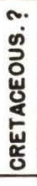 & 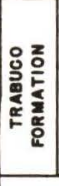 & $\begin{array}{l}\text { ife } \\
\text { thic }\end{array}$ & $\begin{array}{l}\text { Soft, red, doeply-weathered, poorly sorted, coarse, unfossil- } \\
\text { orous boulder conglomerate. Non-marine? Average } \\
\text { ckness } 500-400 \mathrm{ft} \text {. }\end{array}$ \\
\hline 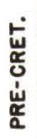 & over & $\begin{array}{l}\text { Metar } \\
\text { rloin }\end{array}$ & $\begin{array}{l}\text { morphosed sedimentary rooks of Triassic age } \\
\text { and intruded by a variety of igneous rocks. }\end{array}$ \\
\hline
\end{tabular}

FIG. 2.-Generalized stratigraphic column of Upper Cretaceous rocks and associated formations in the vicinity of Williams Canyon, Santa Ana Mountains.

proximately at the middle of the Trabuco section; station 3, approximately 10-25 feet below the top of the Trabuco; station 4, approximately 10-25 feet above the base of the Baker conglomerate. 


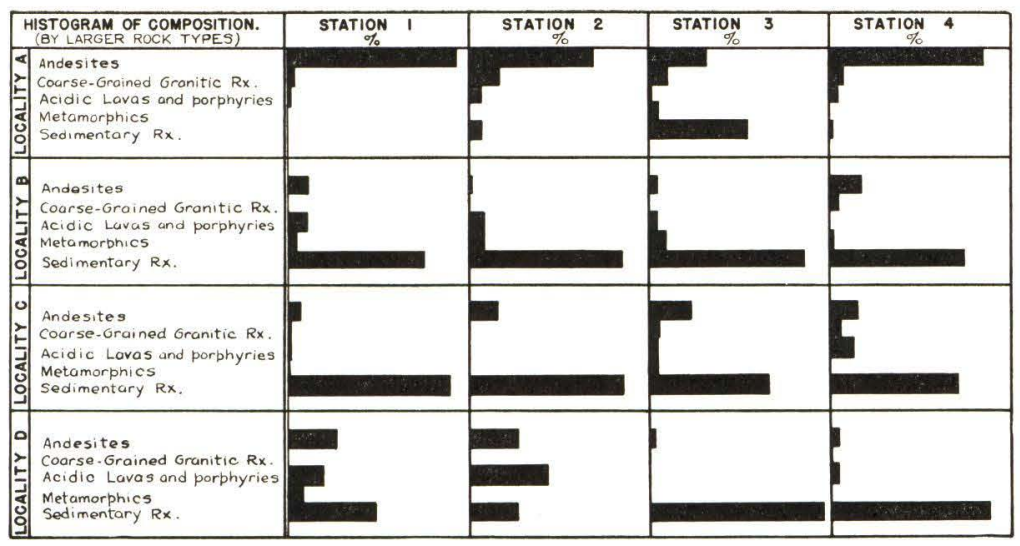

FIg. 3.-Histogram

TABLE 1

Numerical Analysis of Pebble Counts

\begin{tabular}{|c|c|c|c|c|c|c|c|c|c|c|c|c|c|c|c|c|}
\hline \multirow{3}{*}{$\begin{array}{l}\text { COMPOSITION } \\
\text { (BY SPECIES) }\end{array}$} & \multirow{2}{*}{\multicolumn{4}{|c|}{$\begin{array}{l}\text { LOCALITY A } \\
\text { STATION }\end{array}$}} & \multirow{2}{*}{\multicolumn{4}{|c|}{ LOCALITY $B$}} & \multirow{2}{*}{\multicolumn{4}{|c|}{ LOCALITY C }} & \multicolumn{4}{|c|}{ LOCALITY D } \\
\hline & & & & & & & & & & & & & \multicolumn{4}{|c|}{ STATION } \\
\hline & 1 & 2 & 3 & 4 & \multicolumn{3}{|c|}{ 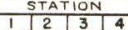 } & 4 & 1 & 2 & 3 & 4 & 1 & 2 & 3 & 14 \\
\hline Andesite Porphyry & 73 & 64 & 20 & 75 & 9 & 1 & 3 & 18 & 6 & 18 & 24 & 12 & 27 & 21 & 1 & 5 \\
\hline $\begin{array}{l}\text { Andesite Breccia } \\
\text { Andesite, Glassy }\end{array}$ & 19 & 4 & $\begin{array}{l}8 \\
5\end{array}$ & $\begin{array}{r}4 \\
12\end{array}$ & 2 & $\circ$ & $i$ & 1 & 1 & 1 & 1 & $i$ & 0 & 9 & $i$ & i \\
\hline & & & & & & & & & & & & & & & & \\
\hline $\begin{array}{l}\text { Granite, Coorse-Grained } \\
\text { Granite, Fine-Grained }\end{array}$ & 2 & 15 & & 6 & 1 & & & 5 & & & 1 & 4 & & & & 1 \\
\hline Gronite, Graphic & & 1 & 8 & 6 & & & & & 3 & & & 1 & & & & \\
\hline $\begin{array}{l}\text { Granito Porphyry } \\
\text { Pegmatite }\end{array}$ & 1 & & & & 9 & 6 & & & & & & 3 & & 16 & & ${ }_{1}^{2}$ \\
\hline $\begin{array}{l}\text { Granodiorite } \\
\text { Aplite }\end{array}$ & 1 & 3 & 2 & 5 & & 2 & 1 & & 5 & & 4 & & & & & \\
\hline Rnyolite? Porphyry & 1 & 4 & 1 & 3 & & & 2 & & & & 4 & 9 & 21 & 31 & & 3 \\
\hline $\begin{array}{l}\text { * Veín Quartz } \\
\text { Basalt ? }\end{array}$ & & & 4 & & 2 & 4 & 2 & 2 & $\begin{array}{l}4 \\
1\end{array}$ & 2 & & i & 3 & & 1 & 5 \\
\hline Serpentine & & & 3 & & 1 & & & & & & 1 & & & & & \\
\hline $\begin{array}{l}\text { Schi } \\
\text { Meto }\end{array}$ & & & & & & & & & 1 & & & & & & & \\
\hline Metamorphics & & & & & 3 & 8 & 9 & 2 & & & 3 & & 7 & & & \\
\hline Arkose & & & 6 & & 37 & 53 & 31 & 28 & 26 & 18 & 10 & 13 & 6 & 16 & 26 & 21 \\
\hline Sondstone & & & & & 1 & 6 & 1 & 1 & 13 & 12 & 2 & & 1 & 1 & 3 & 21 \\
\hline Quartzite & & 4 & 17 & & 17 & 13 & 31 & 29 & 12 & 12 & 18 & 16 & 38 & 4 & 45 & 26 \\
\hline Cher & & 1 & 18 & 1 & 16 & 27 & 27 & 22 & 41 & 39 & 28 & 33 & 2 & 7 & 15 & 26 \\
\hline Shale & & 2 & 11 & & 1 & & 1 & 2 & 3 & 9 & 13 & & 1 & 1 & 25 & 13 \\
\hline $\begin{array}{l}\text { Shale, Siliceous } \\
\text { Conglomerate } \\
\text { Grit }\end{array}$ & & & 4 & & & 2 & 2 & 1 & & & & 4 & & & 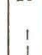 & \\
\hline - Omitted in tables below & & & & & & & & & & & & & & & & \\
\hline TOTAL & 97 & 98 & 108 & 104 & 99 & 102 & 1111 & 1111 & 114 & 111 & 109 & 97 & 100 & 106 & 119 & 102 \\
\hline \multicolumn{17}{|l|}{$\begin{array}{l}\text { COMPOSITION } \\
\text { (BYLAREER ROCK TYPES) }\end{array}$} \\
\hline Ande: & 92 & 68 & 33 & 91 & 11 & 1 & 4 & 19 & 7 & 19 & 25 & 13 & 27 & 30 & 2 & 6 \\
\hline Coar: & 3 & 16 & 10 & 9 & 1 & & & 5 & 5 & & 5 & 5 & & & & 2 \\
\hline Acidic Lavas and & 2 & 7 & 1 & 3 & 9 & 8 & 3 & & 5 & & 4 & 12 & 21 & 47 & & 5 \\
\hline Metar & & 7 & $\begin{array}{r}3 \\
56\end{array}$ & & 4 & 8 & 9 & 2 & 1 & 0 & 4 & & 7 & & & \\
\hline ROUNDING & \multirow{2}{*}{\multicolumn{4}{|c|}{$\%$}} & \multirow{2}{*}{\multicolumn{4}{|c|}{$\%$}} & \multirow{2}{*}{\multicolumn{4}{|c|}{$\%$}} & \multirow{2}{*}{\multicolumn{4}{|c|}{$\%$}} \\
\hline ROUNDING & & & & & & & & & & & & & & & & \\
\hline Rounded & 4 & & 4 & & 1 & 2 & & & 1 & & 1 & & 1 & $\begin{aligned} 1 \\
40\end{aligned}$ & & \\
\hline $\begin{array}{l}\text { Subrounded } \\
\text { Subangular }\end{array}$ & $\begin{array}{l}34 \\
47\end{array}$ & $\begin{array}{l}20 \\
73\end{array}$ & $\begin{array}{l}33 \\
50\end{array}$ & $\begin{array}{l}27 \\
59\end{array}$ & $\begin{array}{l}30 \\
55\end{array}$ & $\begin{array}{l}17 \\
61\end{array}$ & $\begin{array}{r}8 \\
87\end{array}$ & $\begin{array}{l}17 \\
83\end{array}$ & $\begin{array}{l}20 \\
54\end{array}$ & $\begin{array}{l}22 \\
64\end{array}$ & $\begin{array}{l}28 \\
65\end{array}$ & $\begin{array}{l}28 \\
60\end{array}$ & $\begin{array}{l}18 \\
56\end{array}$ & $\begin{array}{l}40 \\
57\end{array}$ & $\begin{array}{l}30 \\
69\end{array}$ & $\begin{array}{l}39 \\
61\end{array}$ \\
\hline Anqular & 15 & 7 & 13 & 4 & 14 & 20 & 5 & & 25 & 14 & 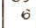 & 12 & 25 & 2 & 1 & \\
\hline PEBBLE SIZE & \multicolumn{4}{|c|}{$\%$} & \multicolumn{4}{|c|}{$\%$} & \multicolumn{4}{|c|}{$\%$} & \multicolumn{4}{|c|}{$\%$} \\
\hline $1^{\prime \prime}-2^{*}$ & 44 & \begin{tabular}{l|l}
54 \\
\end{tabular} & 55 & 36 & 42 & 38 & 51 & 56 & 53 & 57 & 59 & 63 & 54 & 34 & 47 & 36 \\
\hline $2^{\prime \prime}-4^{\prime \prime}$ & 45 & 40 & 42 & 57 & 48 & 58 & 38 & 31 & 38 & 41 & 39 & 55 & 35 & 50 & 41 & 55 \\
\hline $4^{\prime \prime}-6^{\prime}$ & 10 & 5 & 3 & 6 & 10 & 3 & 5 & 10 & 5 & 2 & 2 & 2 & ii & 14 & 12 & 6 \\
\hline $6^{\prime}+$ & 1 & 1 & & 1 & & 1 & 6 & 3 & 4 & & & & & 2 & & 3 \\
\hline
\end{tabular}


The pebbles were taken at random from limited exposures and classified in the field as to (I) rounding, (2) size (i.e., greatest dimension), and (3) composition. The method of classification, while necessarily inexact, is believed to be sufficiently diagnostic to show constant differences, should these exist. The results of the counts are tabulated in the chart (Fig. 3 and Table I).

In the original pebble counts, statistics of rounding were compiled for the separate size groups as given in Figure 3. It was found, however, that the two smaller size groups were so similar in degree of rounding that they might be considered together. Most of the pebbles over four inches in size were subrounded; but these formed so small a proportion of the total count from each station that they could be disregarded in considering the evidence. Therefore, no subdivisions as to size were made in charting the data for rounding.

The evidence gathered in the course of the work is presented under a number of subheadings as follows: (I) general geologic features, (2) structure, (3) color, (4) consolidation, (5) composition, (6) rounding, and (7) pebble size.

\section{GENERAL GEOLOGIC FEATURES}

The Trabuco conglomerate and overlying Baker conglomerate outcrop along a continuous narrow strip for a distance of about ro miles, extending in a northwesterly direction from Trabuco Canyon to Black Star Canyon. Good exposures are numerous. The contact between the Trabuco and Baker conglomerate is usually sharp but in some places appears to be gradational with red and gray beds alternating through a stratigraphic interval of $I^{-2}-20$ feet. The Trabuco is massive. It is hence difficult to get an exact measure of its attitude and thickness. It appears to have about the same strike as the Baker member, for there is no discernible overlap of younger beds upon older throughout the outcrop exposed; and the articles by Woodford and Southwick cited earlier suggest a continuation of this relationship at least I $_{5}$ miles south of the region discussed in this paper. The Trabuco appears to have approximately the same dip as the Baker member, judging by the attitude of the upper surface of the basement rocks and the few dips that can be measured in the conglomerates. These facts indicate that the conglomerates are probably conformable. 
The thickness of the Trabuco cannot be determined precisely but appears to vary between 300 and 400 feet in the area studied. It may thin to the south somewhat as Southwick indicates. The Baker conglomerate south of Silverado Canyon averages about roo feet thick. North of Silverado Canyon it merges above with boulder beds that are developed in the basal part of the Holz shale. The conglomerates in this region are nearly $\mathrm{I}, 000$ feet thick.

The surface expressions of the two conglomerates are markedly different, and the differences are constant. The Trabuco, being much less resistant than either the basement below or the Baker conglomerate above, has been eroded into a persistent, depressed belt lying between two highlands. Bordering this depressed belt on the southwest the Baker conglomerates maintain a steep bare-faced cliff.

\section{STRUCTURE}

In general, the Trabuco conglomerate shows no bedding throughout considerable thicknesses and for long distances along the strike. In a few places sandstone lenses alternate with pebble bands to produce a roughly stratified appearance. In the Baker conglomerate bedding is thick but rarely massive and is usually readily evident on limited outcrops.

COLOR

Probably the most evident difference between the two conglomerates is that of color. The Trabuco is nearly everywhere a deep maroon. The coloring material occurs as a superficial coating on compact and resistant pebbles such as cherts and quartzites, penetrates nearly or quite to the centers of the more friable pebbles, and is present as a fine earthy powder distributed throughout the mass. Arkosic lenses show white sand grains coated with and cemented by a deep-red earthy cement.

The Baker conglomerate is commonly gray or brownish-gray, sometimes with an olive tinge. This color results from a blend of the original varied colors of the individual pebbles altered in places by slight superficial weathering and staining of the exposures.

\section{CONSOLIDATION}

The Trabuco conglomerate is only weakly cemented. In most places unsorted pebbles and cobbles of all sizes have been dumped 
together and the spaces between the larger cobbles filled with small pieces of disintegrated rocks without a binder. In a few places there is local cementation, especially of the arkose lenses, but this is usually not firm. Hillocks and ridges underlain by the Trabuco show softened rounded contours and a tendency to development of a soil cover.

The Baker conglomerate, in contrast, is firm and fairly well cemented and shows some development of a sand matrix. The exposures are usually of fresh rock ordinarily without soil or plant cover.

\section{COMPOSITION}

The principal rock types composing both conglomerates are andesitic rocks and a variety of metamorphosed sedimentaries in varied proportions. The andesites vary considerably in texture. The sedimentary rocks are principally arkoses, arkosic sandstones, quartzites, more or less silicified shales, and cherts. The andesites and sedimentaries together make up 80-90 per cent of the pebbles counted from nearly every station, though from two or three stations in the northernmost locality unusually large numbers of rhyolite and granite-porphyry pebbles are found. The proportion of andesites to sedimentaries varies greatly not only along the strike but at different levels in the same section. In a few places andesites greatly predominate, and sedimentary rocks are almost absent. In other places exactly the opposite condition holds. These variations seem to have no definite relation to position in the section or to locality, and no correlation appears possible between composition of the conglomerates at any given locality and composition of the basement rock near by. In that locality where andesites comprise the greater proportion of pebbles, the basement rock is a thick shale; in another section, where sedimentary rocks predominate in the conglomerates, the basement rock is andesite. Both sediments and andesites found in the conglomerates resemble strongly the basement rocks of those types found near by, and they have most probably been derived from these sources.

Coarse-grained granitic and granodioritic boulders are widely distributed throughout the conglomerates, though in most cases they form less than io per cent of the pebbles counted and at some stations were not found. These rocks comprise most of the largest 
boulders and thus form a larger proportion of the total volume of the conglomerates than their number would indicate. They are rare among the smaller pebbles. Aplites and felsic hypabyssal or effusive rocks are likewise present but generally rare.

ROUNDING

Scarcely any of the pebbles counted in either conglomerate were well rounded. Between I 5 and 40 per cent were subrounded; from 47 to 83 per cent were subangular; while usually less than i 5 per cent were angular, though in three stations the angular pebbles exceed that proportion. There is little basis for separation of the Trabuco and Baker conglomerates on the degree of rounding; and there is no apparent correlation between the observed variations in rounding at the different stations and either locality, stratigraphic position, or composition. Angular and subangular pebbles together make up from 60 to 90 per cent of the pebbles counted, indicating deposition near their source rocks.

PEBBLE SIZE

About 90 per cent of the pebbles counted fell between the I-inch and 4-inch limits, with this majority fairly evenly divided between the $I^{-}-2$-inch and the $2-4$-inch limits. Pebbles from 4 to 6 inches in greatest dimension formed usually less than ro per cent of the number counted. Those exceeding 6 inches in diameter were few and in a number of stations were lacking. No correlation seems possible between position in the section and average pebble size. Hence this character gives no basis for separation.

In summary, the Baker and Trabuco conglomerates are alike in the composition, angularity, and size of their contained pebbles. They differ slightly in bedding; and they differ markedly in topographic expression, color, degree of alteration, and consolidation. These marked differences all appear to be simply manifestations of the different degree of weathering undergone by the two conglomerates.

\section{CONCLUSIONS}

The Baker conglomerate is evidently marine. Packard $^{9}$ and Moore ${ }^{10}$ have both reported finding marine fossils in the matrix, and the member grades up into and in places interfingers with sandstones

$$
{ }_{9} \text { "Faunal Studies....," op. cit., p. I4I. } \quad{ }^{\mathrm{r} 0} \text { Op. cit., p. } 58 .
$$


containing marine fossils. The member apparently represents a typical basal conglomerate.

Unequivocal evidence for the origin of the Trabuco conglomerate is lacking. Joseph Barrell ${ }^{\text {I }}$ has argued that marine basal conglomerates of an advancing sea will usually not form to thicknesses greater than too feet, though thicker conglomerates may form where a sea transgresses a land of considerable relief. He states also that a sea advancing across gravelly coastal or fluviatile deposits will usually deposit a thin basal conglomerate, unless the land surface submerged has a rather steep seaward slope, and therefore the principal thickness of the basal gravels will be nonmarine. Both of these statements would tend to support a continental origin for the Trabuco. It is probable, however, that the maximum observed thickness of the Trabuco is well within the thickness possible for marine conglomerates accumulating under exceptional conditions. Barrell's arguments thus give little basis for determining the origin of the Trabuco conglomerate.

Packard, in discussing the Trabuco formation, stated: "The peculiar color, the angular form of most of the pebbles and sand grains, and the lack of marine fossils suggest that the Trabuco formation was deposited upon a narrow coastal plain by torrential streams arising in a mountainous region but a short distance to the eastward." ${ }^{2}$ The Trabuco appears to be wholly unfossiliferous, and this at best gives simply negative evidence for the origin of the formation. The angularity of the pebbles in the Trabuco can scarcely be considered valid evidence of nonmarine origin, considering the equal angularity of the pebbles of the overlying Baker conglomerate.

It might be argued that the color and the altered condition of the Trabuco boulders result from redeposition of red and weathered source rock. This idea is rejected for two reasons. First, many of the larger cobbles - particularly the andesites - are so badly decayed that only the support of surrounding rock on all sides permits them to maintain their shape. Upon removal of this support the cobbles disintegrate under their own weight. Obviously such rocks could not

${ }_{11}$ "Marine and Terrestrial Conglomerates," Bull. Geol. Soc. Amer., Vol. XXXVI (1925), pp. 306-I2.

ז2 "Faunal Studies...., , op.cit., p. I4I. 
survive transportation. Second, the action of any aqueous transporting medium would tend to separate the finer, clayey particles of the conglomerate from the sands and pebbles and would either leave the pebbles washed clean or result in alternating beds of clay and coarser material depending upon the uniformity of action of the medium. It may be assumed, then, that the Trabuco conglomerate was weathered to its present condition after its deposition.

As yet, the conditions under which red sediments form are not completely understood. The older view - that red beds indicate continental deposition in desert or arid environments - is no longer generally held. It is now believed by some ${ }^{13}$ that red sediments, excepting those formed from originally red source rocks, are most generally formed on land in an environment of fairly warm climate, abundant but seasonal rainfall, and good drainage. If the climate is too arid, oxidation does not take place, and the color of the sediment represents the mass effect of the colors of the source rocks. If the drainage is poor, reduction of iron compounds rather than oxidation is likely to result, and the altered rock will be gray or black. Red muds colored by iron oxide are known to accumulate in the deep sea; but I know of no example of shallow-water clastics, such as conglomerates, being oxidized to red in a marine environment. It therefore seems probable that the Trabuco was altered to its present condition above the sea.

In considering the hypothesis interpreting the Trabuco as a weathered phase of the marine basal conglomerate, it is difficult to understand how any system of circulating meteoric waters would restrict its oxidizing action so uniformly and over such a broad area to the lower three-quarters of a porous rock body 500 feet thick. One would expect considerable irregularity in the upper surface of such an altered zone, depending upon the varying permeability of the rock, the contours of the land surface at the time alteration took place, and the drainage pattern of the country. Also, the unaltered conglomerate is above, the altered rock below; meteoric waters affecting the Trabuco conglomerate would necessarily first have to

${ }_{13}$ W. H. Twenhofel, Treatise on Sedimentation (2d ed.; Baltimore: Williams \& Wilkins Co., r932), pp. 777-78; R. D. Reed, "Sespe Formation, California," Bull. A mer. Assoc. Pet. Geol., Vol. XIII (1929), p. 505. 
pass through the upper beds and, as the oxidizing effect of such waters is ordinarily most active near the surface, the uppermost beds should be most thoroughly weathered, other things being equal. The explanation has been offered that the Trabuco is more permeable than the Baker conglomerate and contains a higher percentage of ferruginous minerals and more arkose. But it seems probable that the greater permeability of the Trabuco is due to the fact that it has been weathered rather than the reverse; and a reasonable doubt exists that there is sufficient difference in composition to be of moment. A quantitative determination of the relative proportions of arkose and iron-bearing minerals of the two conglomerates is difficult without a thorough petrologic analysis of the matrixes; but even superficial examination of the matrix of the Baker member shows that it is highly arkosic and contains much unaltered mica and other ferromagnesian minerals such as hornblende and pyroxenes.

One of the points advanced to show the essential unity of the Trabuco and Baker conglomerates is that the alteration of the Trabuco sediments took place after deposition of the formation. Available evidence supports this conclusion fully; but this does not in any way indicate that alteration of the Trabuco took place after deposition of the Baker conglomerate. If the Trabuco is interpreted as a flood-plain deposit - as Packard suggests - similar to the washes that are now forming along the piedmont fronts of many California ranges, we would expect alteration under suitable climatic conditions to begin as soon as deposition took place and to continue as long as the deposit remained above the sea. The basal layers of the flood plain, being longest subject to weathering, might be more altered than those above. Upon transgression of the sea across the flood plain, fresh marine conglomerates would accumulate directly above the weathered conglomerate. The final succession would therefore be what we now find in the Santa Ana Mountains. The more resistant rocks present in the weathered flood-plain sediments would be reworked as the basal conglomerate of the advancing sea, together with additional material brought down by streams debouching along the coast.

It has already been noted that there is evidence that the Trabuco formation extends I 5 miles south of the region here studied and that 
a red conglomerate, lying below marine Upper Cretaceous and above Triassic(?) metamorphics, has been penetrated in wells near San Diego. H. W. Hoots ${ }^{\mathrm{r}}{ }^{4}$ has likewise described, in the Santa Monica Mountains a few miles west of Los Angeles, a red incoherent, deeply weathered conglomerate overlying the Santa Monica slates of undetermined age and underlying marine Upper Cretaceous conglomerates and sandstones. It is not known that the basal marine Cretaceous beds of San Diego and of the Santa Monica Mountains are the same age as the Baker conglomerate and overlying fossiliferous sandstones; but there is some evidence that this may be so. The lithologic succession is similar in the three areas.

To explain the features observed we may present several alternative hypotheses: (I) Previous to the transgression of the Upper Cretaceous sea in southern California, similar conglomerates accumulated over large areas, were subaerially weathered, and then were covered by the sea. (2) The lower part of the marine Upper Cretaceous basal conglomerate was weathered after deposition throughout a thickness of several hundred feet, over a distance of nearly I 50 miles, and to an advanced degree. The weathering did not affect the top one-third or one-quarter of the basal conglomerate. (3) The Trabuco conglomerate might be interpreted as a marine deposit that had been uplifted, weathered subaerially, and subsequently transgressed by the Upper Cretaceous sea. There seem to be no reasons for adopting such a hypothesis, and several facts oppose it. It would require elevation of the land at least equal to the thickness of the formation to permit weathering of the mass to its base and would require maintenance of this elevation for a time sufficiently long to permit advanced decomposition of the material. Erosion, accelerated by the uplift, would be working on an unconsolidated deposit. Streams reaching the coast would necessarily cross the outcrop of the Trabuco and would doubtless rapidly cut channels to the base of the formation. Upon resubmergence of the area, these channels would tend to fill with unaltered sediments. The end result would be a formation of discontinuous distribution and very variable thickness. These features are not to be seen along the Trabuco outcrop. On the whole the first explanation given seems most reasonable and probable.

${ }_{4}^{14}$ U.S. Geol. Surv. Prof. Paper ${ }^{6} 6-C$ (1931), p. 90. 
In summary, available evidence supports Packard's theory of origin of the Trabuco conglomerate. The formation is probably land laid, although evidence for this is neither so full nor so precise as is desirable. It is held that, whatever its origin, the Trabuco is a stratigraphic and depositional unit, distinct from the Baker conglomerate. The alteration of the Trabuco apparently took place after its deposition and before deposition of the Baker member and is believed to be due to ordinary atmospheric weathering processes and circulation of ground waters.

An important by-product of this study is the indication that two conglomerates of different age and origin may be so similar in composition and rounding of the pebbles that they cannot be distinguished in the field by these features. In this case the similarity appears to be due to the probability that the conglomerates had a common source rock; the pebbles and boulders in each case were carried but a short distance before deposition and were laid down rapidly. Had arid climatic conditions prevented deep weathering of the Trabuco, separation of the two conglomerates by usual field methods would be difficult if not impossible. This suggests that a thick unfossiliferous conglomerate with apparently uniform physical features may have accumulated in more than one type of environment. It is hoped that further development of methods similar to those used by W. C. Krumbein ${ }^{15}$ in studying the gravels of San Gabriel Canyon may furnish dependable criteria for determining the origins of such deposits.

Acknowledgments. - This study was carried forward under the supervision of Dr. Ian Campbell, of the California Institute of Technology, who has helped me greatly with advice and criticism. Dr. G. H. Anderson, of the Texas Power and Light Company, has been in the field with me on a number of occasions, has helped in determining some of the puzzling rock types found in the conglomerates, and has advised me on broader features of the problem. Mr. J. M. Holloway, of the California Institute, drafted the sketch maps and figures. I am glad to acknowledge the help I have had from these friends.

${ }_{15}$ “Flood Gravels of San Gabriel Canyon, California," Bull. Geol.Soc. Amer., Vol. LI, No. 5 (May I, I940), pp. 639-76. 